\title{
Investigation influence of human sweat and moisture on the resistance to abrasion of woolen fabrics
}

\begin{abstract}
When using process, abrasions in some part of the clothes due to friction are frequently encountered event. Generally, abrasion of textile material due to friction is complex process, takes place under the action with one or more of the physical, chemical, biological and mechanical factors and results in with deterioration or dispersion of the material. One of the effective biological factors is sweat. Abrasions due to friction take place under the influence of a sweat in some areas of clothes, such as between the trouser legs, jacket's arms. In this study, it has examined that how abrasion changes resistance of clean woolen cloths under the influence of human sweat. Various woolen fabrics with different parameters have been subjected to tests for resistance to abrasion under normal conditions. Samples were tested dry and after wetting with pure water and a solution of human sweat. The results were compared. It is shown that, wet abrasion resistance of woolen fabric is lower than the dry form. Abrasion resistance of clean wool fabrics taken up moisture $25 \%$ of the weight of the normal environment can lose between $35 \% \ldots 55 \%$ due to friction in normal ambient conditions. Clean wool fabrics lose their abrasion resistance less in comparison with pure water under the effect of human sweat.
\end{abstract}

Keywords: abrasion resistance, woolen clothes, loss of abrasion resistance due to moisture, loss of abrasion resistance due to sweating
Volume 2 Issue I - 2017

\author{
Nazim Pasayev \\ Department of Textile Engineering, Erciyes University, Turkey
}

Correspondence: Nazim Pasayev, Erciyes University Faculty of Engineering Department of Textile Engineering, Kayseri, Turkey, Tel 537276670I,Email npasayev@erciyes.edu.tr

Received: March 21, 2017 | Published: June 05, 2017

\section{Introduction}

It is defined that the abrasion of textile materials or textile products due to friction is totally or partially losing the features of material with together losing their utility friction. Abrasion of textile materials due to friction is caused the chance in the surface properties, loss of mechanical properties and material mass and increase in permeability of materials.

Abrasion due to friction in some part of the clothes at using process is frequently encountered event. As a result, it is impossible that it can be glow, thinning, loss of strength, tear, etc. at in the different regions of clothes. Generally, abrasion of the textile material due to friction is complex process, takes place under the action with one or more of the physical, chemical, biological and mechanical factors and result in with deterioration or dispersion of the material. The one of the effective biological factors is sweat in here. Abrasions due to friction take place under the influence of a sweat in some areas of clothes, such as between the trouser legs, jacket's arms. In this study, it has examined that how changed the wear resistance of clean woolen cloths under the influence of human perspiration.

Some studies about how sweat affects the properties of textile materials have been made. However, these studies generally relate to color fastness of textile materials and have not reviewed the wear properties. As it is known, $99 \%$ of the sweat is consisting of hypotonic water. ${ }^{1}$ Therefore, textile products, which are exposed to sweat, while also subjected to water. Effect of water for abrasion resistance of textile materials were investigated in several studies.

Researches carried out in the $60 \mathrm{~s}$ and 70 s showed that abrasion resistance of the fabric had falled under the influence of moisture..$^{2-7}$ McNally and his friend have argued that abrasion resistance of cotton fabric in wet conditions should not be lower than dry conditions. ${ }^{6}$
This possibility has not been confirmed in later studies. In many studied, it has seen that abrasion resistance of cellulose-based textile materials decreased under the influence of moisture. ${ }^{2,3,7}$ McNally and his friend emphasized that existing methods are not enough for testing abrasion resistance of wet fabric. ${ }^{6}$ This question drew attention Škoc and his co-author. To remedy the situation, they modified the method of testing the current standard (ISO 12947-3) Škoc et al. ${ }^{8}$ Mass loss from abrasion in wet fabric is higher than dry fabrics according to the results obtained by them. Nhan and his co-author emphasized that in addition to the relative humidity environment abrasion woolen fabrics substantially influences also amount of moisture in the fabric Nhan et al. ${ }^{4}$ Their conclusions were confirmed by Holm and his friend Holme et al. ${ }^{9}$ In this study, developed a new method for testing abrasion wet textiles. Using the developed method investigated changes in the degree of abrasion pure wool fabrics under the influence of moisture and human sweat.

\section{Materials and method}

\section{Materials}

$100 \%$ wool fabrics were used in the experiments. Technical characteristics of these fabrics are given in Table 1.

Tests for abrasion of selected tissue samples were carried out in the state of dry, moistened with distilled water and moistened with a solution of human sweat.

Sweat solutions based alkaline and acid and treated water were prepared to examine the effect of abrasion resistance for sweat in accordance with ISO 105-E04 standard. This is because of the sweat has different properties in different parts of body. Sweat in some areas of the human body showing acidic properties when in other areas detects alkaline properties. The content of sweat can change 
according also to the states human. The content of 1 liter acid and alkaline based sweat solution in Table 2 . The chemicals in table were put in pure water and alkaline and acidic chemicals sweat solutions were prepared according to the demands of standard.

\section{Method}

Many laboratory methods have been developed for evaluating the abrasion resistance of textile materials. These methods are based on the use of devices which simulate generally friction case. ${ }^{10}$ ISO $12947-$ 2 is used to determine the abrasion resistance of fabric from existing standards. However, this standard doesn't suggest the methods related Table I Technical characteristics of the selected fabric to measurement of abrasion resistance for damp fabrics. Scotch and his friend have modified the ISO 12947 for this purpose. ${ }^{10}$ However, the methods suggested by them demands that samples have should full wetted. But the clothes, in most cases when you use not completely wet. On the other hand, was not taken into consideration in this work is that when tested in Martindale apparatus, because the sample is heated, it dries out continuously. However, Nhan and his friend have shown that the fabric temperature had increase $2^{\circ} \mathrm{C}$ after the first 100 friction period during testing the abrasion resistance of wool fabrics, after 10000 periods, temperature had $6^{\circ} \mathrm{C} .{ }^{4}$ This temperature rise must cause dry the fabric over time.

\begin{tabular}{|c|c|c|c|c|c|c|c|c|c|c|}
\hline \multirow[t]{2}{*}{ Fabric } & \multirow[t]{2}{*}{$\begin{array}{l}\text { The content } \\
\text { of fabric fiber }\end{array}$} & \multicolumn{2}{|c|}{$\begin{array}{l}\text { Number of fabric } \\
\text { yarn, tex }\end{array}$} & \multirow[t]{2}{*}{$\begin{array}{l}\text { Density of } \\
\text { fabric surface, } \\
\mathrm{g} / \mathrm{m}^{2}\end{array}$} & \multicolumn{2}{|c|}{$\begin{array}{l}\text { Fabric frequency } \\
\text { (wirel/cm) }\end{array}$} & \multicolumn{2}{|c|}{$\begin{array}{l}\text { Twist of fabric } \\
\text { yarn (rounder/m) }\end{array}$} & \multicolumn{2}{|c|}{$\begin{array}{l}\text { Fabric thickness, } \\
\mathrm{mm}\end{array}$} \\
\hline & & Warp & Weft & & $\begin{array}{l}\text { For } \\
\text { warp }\end{array}$ & $\begin{array}{l}\text { For } \\
\text { weft }\end{array}$ & Warp & Weft & $\begin{array}{l}\text { Before } \\
\text { testing }\end{array}$ & $\begin{array}{l}\text { After } \\
\text { testing }\end{array}$ \\
\hline I & $100 \%$ wool & 39,62 & 38,21 & $2|2,6|$ & 26 & 24 & 508 & 481 & 0,60 & 0,57 \\
\hline 2 & $100 \%$ wool & 50,52 & 49,56 & 239,25 & 24 & 22 & 467 & 413 & 0,53 & 0,49 \\
\hline 3 & $100 \%$ wool & 26,57 & 27,36 & 177,09 & 32 & 28 & 1087 & 1057 & $0,4 \mathrm{I}$ & 0,39 \\
\hline 4 & $100 \%$ wool & 32,28 & 28,77 & 219,04 & 36 & 30 & 610 & 612 & 0,57 & 0,55 \\
\hline 5 & $100 \%$ wool & 23,39 & 24,89 & $15 \mid, 43$ & 32 & 28 & 883 & 790 & 0,28 & 0,27 \\
\hline
\end{tabular}

Table 2 The content of human sweat solution of acid and alkaline bases on standard ISO I05-E04

\begin{tabular}{lll}
\hline The content of sweat solution based alkaline & The content of sweat solution based acid \\
\hline Chemicals & $\begin{array}{l}\text { Amount, } \\
\text { gr }\end{array}$ & Chemicals \\
\hline Histidin hidroklorid monohidrat $\left(\mathrm{C}_{6} \mathrm{H}_{9} \mathrm{O}_{2} \mathrm{~N}_{3} \cdot \mathrm{HCl} \cdot \mathrm{H}_{2} \mathrm{O}\right)$ & 0,5 & Histidine hydrochloride monohydrate $\left(\mathrm{C}_{6} \mathrm{H}_{9} \mathrm{O}_{2} \mathrm{~N}_{3} \cdot \mathrm{HCl}_{2} \mathrm{H}_{2} \mathrm{O}\right)$ \\
Sodium chloride $(\mathrm{NaCl})$ & 5,0 & Sodium chloride $(\mathrm{NaCl})$ \\
Disodium hydrogen orthosphate dodehidrat $\left(\mathrm{Na}_{2} \cdot \mathrm{HPO}_{4} \cdot 2 \mathrm{H}_{2} \mathrm{O}\right)$ & 5,0 & Disodium hydrogen orthosphate dodehidrat $\left(\mathrm{Na}_{2} \cdot \mathrm{HPO} \cdot 2 \mathrm{H}_{2} \mathrm{O}\right) \quad 2,2$ \\
\hline
\end{tabular}

A different method was used developed by us in the presented study. ISO 12947-2 was taken as a basis, but the preparation of the samples was carried out in many different ways. The fabrics were selected for abrasion process with Martindale in accordance with demanded standard and cut, conditioned in normal ambient conditions. Abradant was also cutting from the material tested.

Since you want to test the wet tissue, it is necessary to ensure the constancy of the samples humidity. Therefore, you need to somehow compensate the sample constantly lost moisture due to evaporation. We chose to the transfer moisture sample during testing, out of the bottom with a wet swab. To this end, according to the size of a sample cutting of a protection layer of polyethylene and tampon of nonwoven fabric containing cotton. Tampon materials cuttin from nonwoven were kept in sweat solutions or clean water in a Petri for 30minutes. Samples were weighed on precision scales and the is wetted by spraying a solution of human sweat or clean water $20 \%$ by weight under normal conditions. The samples were then placed in a device according Martindale, as shown in Figure 1.

Device was stopped each $3000 \mathrm{rpm}$ and the weight of the pledge was checked. When this weight is reduced by more than $2 \%$, sweat solution and water were supplemented to the pledged and humidity content was converted to initial status. Thus, with decreasing moisture content of the sample, moisture is transferred from the swab in the sample and thus ensures stability of moisture samples. Because of using the tested fabric as abradant, the amount of sweat or water was kept under control in the same way. To prevent transfer of moisture from the was placed the polyethylene film between tampon and felt pad device in Figure 1.

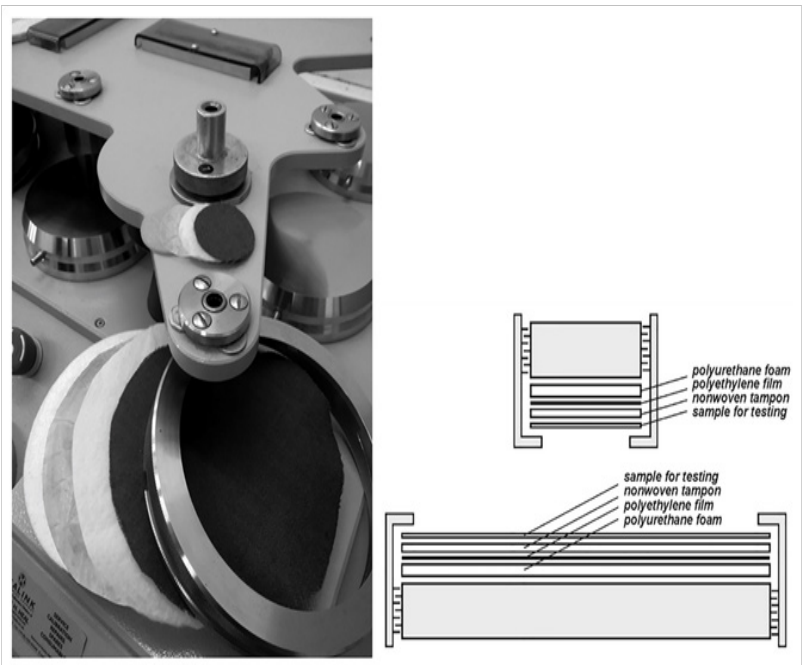

Figure I Placing the samples to be tested. 
Three kinds of sample from each material were tested for abrasion test under the influence of the sweat liquor and clean water. The end of the test procedure is defined according to ISO 12947-2 standard.

\section{Discussion}

Selected fabrics were tested for abrasion test in dry form, then with sweat solution and moistened form. The test results are given in Table 3 .

Wet-abrasion of woolen fabric is lower than dry form as seen from Table. This is highly depending on wet swelling of wool fibers and losing strength markedly. Because abrasion resistance of fibers is significantly determined with strength of the fibers. The loss of Table 3 Abrasion resistance values of fabrics exposed to the effects of sweat and water

\begin{tabular}{llllll}
\hline \multirow{2}{*}{ Fabric } & The content of fabric fiber & \multicolumn{2}{l}{ The resistance of fabric abrasion, I03 rpm } \\
\cline { 3 - 6 } & & With alkaline sweat solution & With acidic sweat solution & With pure water & Dry \\
\hline 1 & $100 \%$ wool & 5,8 & 5,70 & 5,5 & 12,0 \\
2 & $100 \%$ wool & 13,0 & 13,8 & 11,5 & 20,0 \\
3 & $100 \%$ wool & 7,8 & 9,6 & 6,5 & 14,6 \\
4 & $100 \%$ wool & 15,0 & 14,2 & 12,50 & 19,2 \\
5 & $100 \%$ wool & 9,0 & 9,00 & 7,20 & 11,5 \\
\hline
\end{tabular}

\section{Results}

A. For testing abrasion wetted fabrics standard method exists tissues. To solve this problem, based on existing standards, developed a test method.

B. Applying the developed method was subjected to tests for wear pure wool fabrics, which are wetted with moisture or a solution of human sweat by $20 \%$ of its weight in normal conditions.

C. Based on these results, we can say that wet abrasion resistance of woolen fabric is lower than the dry form. Abrasion resistance of clean wool fabrics taken up moisture $25 \%$ of the weight of the normal environment can lose between $35 \% . .55 \%$ due to friction in normal ambient conditions.

D. Clean wool fabrics lose their abrasion resistance less in comparison with pure water under the effect of human sweat.

\section{Acknowledgements}

The author would like to thank company YÜNSA the for the supply of woolen fabrics for this project.

\section{Conflict of interest}

Author declares there is no conflict of interest in publishing the article

\section{References}

1. Grashin RA, Barbie BB, Babkin AV. Comparative evaluation of the effect of liposomal and conventional soaps on the functional activity of apocrine sweat glands and the chemical composition of human sweat. $J$ Dermatology \& Cosmetology. 2004;1:39-42. strength for wool fibers is reported the about $30 \%$ in literature. ${ }^{11}$ According to our results, abrasion resistance of clean wool fabrics taken up moisture $25 \%$ of the weight of the normal environment can lose between $35 \% \ldots 55 \%$ due to friction in normal ambient conditions.

On the other hand, it is observed that abrasion resistance of fabrics was exposed the acidic and alkaline sweat solution is higher the fabrics were exposed the pure water. This means that abrasion resistance of fabrics exposed the sweat effect is essentially due to water. Because of substances contained in sweat has a larger molecular size, fibers cannot penetrate between the macro-molecules, remain on the fibers surface and exhibit role of buffer. As a result, abrasion resistance of fibers exposed the sweat solution is higher than pure water.
2. Goynes WR, Rollins ML. A Scanning-Electron Microscope Study of Washer-Dryer Abrasion in Cotton Fabrics. Text Res J. 1971;41(3):226-231

3. Chippendale P. Wear, Abrasion, and Laundering of Cotton Fabric. J Textile Inst. 1963;54(11):T445-T463.

4. Nhan LG, Denby EF. The Effect of Humidity on the Abrasion-resistance of Wool Fabric. J Textile Inst. 1979;70(6):264-268.

5. Peppas A. The effects of chemical treatments on the abrasion resistance of wool fabrics. PhD thesis, University of Leeds, UK; 1981.

6. McNally JP, McCord FA. Cotton Quality Study, V: Resistance to Abrasion. Text Res J. 1960;30(10):715-751.

7. Rollins ML, Degruy IV, Hensarling TP, et al. Abrasion Phenomena in Durable-Press Cotton Fabrics A Microscopical View. Text Res J. 1970;40(10):903-916.

8. Škoc MS, Pezelj E. Abrasion Resistance of High Performance Fabrics. Abrasion Resistance of Materials. In Tech, Rijeka, Croatia; 2012. p. $35-52$.

9. Holme I, Peppas A. The Wet Abrasion of Woven Wool Fabrics. J Textile Inst. 1981;72(6):263-267.

10. Saville BP. Physical Testing of Textiles. CRC Press, Cambridge: Woodhead Publishing Limited; 1999. p. 336.

11. Kukin GN, ANSoloviev, Koblyakov AI. Textile Materials Science (textile fabrics and products). Moscow; 1992. 